\title{
The effect of methoxyflurane analgesia on renal function in burned patients: an investigation
}

\author{
S. M. LAIRD \\ B.A., M.B., B.Ch., B.A.O., F.F.A., R.C.S. \\ Kathleen M. R. Chrystal* \\ M.B., Ch.B., F.R.C.S. (Ed.) \\ Welsh Plastic and Reconstructive Surgery Centre, St Lawrence Hospital, \\ Chepstow, Monmouthshire, South Wales
}

\section{Summary}

This paper reports an investigation into evidence of renal dysfunction following methoxyflurane analgesia for burns dressings.

Twelve patients were studied and small increases in serum uric acid were observed in all of them. This increase may have been dose-related.

Four patients had small but consistent increases in blood urea nitrogen and serum creatinine on the third post-dressing day.

No definite conclusions can be adduced and further research is needed.

IN 1966 Crandell, Pappas \& MacDonald reported sixteen cases of high-output renal failure among ninety-four patients who had been anaesthetized with methoxyflurane. Subsequently, there were only infrequent reports of nephrotoxic reactions following inhalation of methoxyflurane (Austin \& Villandry, 1967; Elkington, Goffinet \& Conn, 1968; Kuzucu, 1970; Lapointe \& Belle-Binda, 1970; Lebowitz, 1969; Mignault, Labrecque \& Hamel, 1970; Panner et al., 1970; Pezzi, Frobese \& Greenberg, 1966; Snyder, McCall \& Hayes, 1966; Taves et al., 1970) and most anaesthetists believed that renal dysfunction following methoxyflurane anaesthesia was extremely rare.

In April 1971, Mazze, Shue \& Jackson published the results of a randomized, prospective, clinical evaluation of the effects of methoxyflurane anaesthesia and halothane anaesthesia on renal function. They investigated eighteen patients. Ten patients were anaesthetized with halothane, and four of these patients were among the twelve who were given methoxyflurane.

In order to minimize the number of variable factors, the method of anaesthesia was unorthodox. Atropine alone was used as a premedication. The patients were anaesthetized with halothane and oxygen, or methoxyflurane and oxygen. Nitrous oxide

* Now Senior Registrar in Plastic Surgery, Bangour General Hospital, Broxburn, West Lothian, Scotland. was not employed. Suxamethonium was given to facilitate endotracheal intubation. Patients were then curarized and ventilated to maintain a $\mathrm{PaCO}_{2}$ of between $35 \mathrm{mmHg}$ and $40 \mathrm{mmHg}$. When methoxyflurane was used the vaporizer setting for induction was $1.0-1.5 \%$, with $0.3-0.5 \%$ settings for maintenance. When halothane was used the induction vaporizer setting was $3.5 \%$ and anaesthesia was maintained with $1.0-1.5 \%$ halothane.

All the patients anaesthetized with methoxyflurane developed an inability to retain body water despite increasing serum osmolality. In some patients the diuresis failed to respond to exogenous antidiuretic hormone. Patients also developed hypernatraemia, a rise in blood urea nitrogen and a rise in serum uric acid. The smallest rise in serum uric acid was $33 \%$ in methoxyflurane-anaesthetized patients compared with a maximum rise of $15 \%$ in patients anaesthetized with halothane. The average duration of the operation in the methoxyflurane group was $4.06 \mathrm{hr}$. The longest operation lasted $5 \mathrm{hr} 45 \mathrm{~min}$ and the shortest $2 \mathrm{hr} 30 \mathrm{~min}$. The amount of methoxyflurane inhaled by these patients was, therefore, considerable.

Methoxyflurane has been used in subanaesthetic concentrations as an obstetric analgesic for a number of years. Its use as an analgesic for burns dressings was first reported by Packer \& Titel in 1969. No instances of renal dysfunction have been reported following methoxyflurane analgesia in burned patients.

We decided to set up an investigation to establish whether there was any clinical or biochemical evidence of renal dysfunction following analgesia with subanaesthetic concentrations of methoxyflurane for burns dressings.

The patients for the study were chosen at random but the following categories were excluded:

(1) Children aged 15 years or under.

(2) Patients with symptoms, signs or a previous history of impaired renal function. 
(3) Patients who had been given methoxyflurane analgesia for their dressings on admission to the Burns Unit.

\section{Method}

The first group of eight patients was studied during the $24 \mathrm{hr}$ prior to the dressing in order to establish a base line. They were then studied on the day of the dressing and on each of the ensuing 2 days.

Fluid balance charts were to be kept for each patient on each of the 4 days. In spite of the closest possible supervision the data were incomplete and these observations are, therefore, valueless.

The following blood constituents were estimated on the same 4 days, and to ensure comparability the blood samples were always taken at $9.00 \mathrm{am}-$ blood urea, serum uric acid, sodium, potassium, plasma proteins, blood urea nitrogen (BUN). Eight patients were investigated in this group and four of these patients were studied on two occasions.

There were two specimens of the patient's blood before exposure to methoxyflurane, and two specimens after exposure. For the purposes of analysis the pre-dressing estimations have been averaged and compared with the average of the two post-dressing estimations.

\section{Results}

There were no significant alterations in the levels of urea, blood urea nitrogen, sodium, potassium, or plasma proteins. All of these blood constituents could have been expected to rise had there been loss of body water and impairment of renal function.

Serum uric acid did rise appreciably and the results are shown in Table 1.

It is difficult to calculate the amount of methoxyflurane absorbed by each patient. Methoxyflurane is very soluble in rubber, and is, therefore, taken up by the tubing between the vaporizer and the patient. As inhalations proceed the tubing becomes more impregnated with methoxyflurane and the concentration inhaled by the patient approaches that produced by the vaporizer (Eger \& Brandstater, 1963; Eger, 1964). The methoxyflurane 'Factor' shown in the tables is simply the vaporizer setting on the draw-over Pentec inhaler multiplied by the duration of the inhalation in minutes.

The percentage rise in serum uric acid appears to be roughly proportional to the methoxyflurane 'Factor'.

The next four patients to be investigated had blood samples taken on the morning of the day of the dressing and on each of the ensuing 3 days. There was thus one blood specimen before exposure to methoxyflurane and three specimens after exposure. No attempt was made to keep fluid balance charts for these patients.

It was decided to estimate blood creatinine in these patients, and in order to minimize the amount of blood taken estimations of sodium, potassium and urea were omitted from this series.

The changes in serum uric acid are shown in Table 2, and those for blood urea nitrogen (BUN) and creatinine in Table 3.

Serum acid levels start to fall on the third postdressing day. On the same day blood urea nitrogen (BUN) and creatinine show a slight increase.

Patient 12 had a dressing carried out with trichloroethylene analgesia, and the results are shown in Table 4. These results are similar to those observed when this patient was given methoxyflurane.

\section{Discussion}

Uric acid is freely excreted in the glomerular filtrate and all but about $2 \%$ of this is reabsorbed by the proximal tubule. Uric acid is actively secreted by

TABLE 1.

\begin{tabular}{|c|c|c|c|c|c|}
\hline Patient & $\%$ burn & $\begin{array}{l}\text { Pre-dressing } \\
\text { serum uric acid } \\
(\mathrm{mg} / 100 \mathrm{ml})\end{array}$ & $\begin{array}{l}\text { Methoxyflurane* } \\
\text { 'Factor' }\end{array}$ & $\begin{array}{c}\text { Change in } \\
\text { serum uric acid } \\
(\mathrm{mg} / 100 \mathrm{ml})\end{array}$ & $\begin{array}{c}\% \\
\text { change }\end{array}$ \\
\hline 1 & 3 & $\begin{array}{l}2.75 \\
2.95\end{array}$ & $\begin{array}{l}10 \cdot 0 \\
12 \cdot 5\end{array}$ & $\begin{array}{l}-0.10 \\
+0.15\end{array}$ & $\begin{array}{l}-3 \cdot 6 \\
+\quad 5.0\end{array}$ \\
\hline 2 & 5 & $\begin{array}{l}4 \cdot 45 \\
4 \cdot 90\end{array}$ & $\begin{array}{l}12 \cdot 5 \\
12 \cdot 0\end{array}$ & $\begin{array}{l}+1.05 \\
+0.95\end{array}$ & $\begin{array}{l}+23 \cdot 6 \\
+19 \cdot 4\end{array}$ \\
\hline 3 & 10 & $\begin{array}{l}6.90 \\
5 \cdot 25\end{array}$ & $\begin{array}{l}14 \cdot 0 \\
22 \cdot 5\end{array}$ & $\begin{array}{l}+1.40 \\
+3.55\end{array}$ & $\begin{array}{l}+20 \cdot 3 \\
+67 \cdot 6\end{array}$ \\
\hline 4 & 23 & $\begin{array}{l}2 \cdot 95 \\
3 \cdot 45\end{array}$ & $\begin{array}{r}20 \cdot 0 \\
8 \cdot 0\end{array}$ & $\begin{array}{l}+0.60 \\
+0.55\end{array}$ & $\begin{array}{l}+20 \cdot 3 \\
+15 \cdot 9\end{array}$ \\
\hline $\begin{array}{l}5 \\
6 \\
7 \\
8\end{array}$ & $\begin{array}{r}5 \\
14 \\
24 \\
8\end{array}$ & $\begin{array}{l}3 \cdot 65 \\
3 \cdot 25 \\
3 \cdot 10 \\
5 \cdot 95 \\
\end{array}$ & $\begin{array}{l}12 \cdot 0 \\
15 \cdot 0 \\
10 \cdot 8 \\
10 \cdot 0\end{array}$ & $\begin{array}{l}+1.20 \\
+1.45 \\
+0.30 \\
-0.50\end{array}$ & $\begin{array}{r}+32 \cdot 8 \\
+\quad 46 \cdot 6 \\
+\quad 9 \cdot 7 \\
-\quad 5 \cdot 0\end{array}$ \\
\hline
\end{tabular}
minutes. 
TABLE 2.

\begin{tabular}{|c|c|c|c|c|c|c|}
\hline Patient & $\%$ burn & $\begin{array}{l}\text { Pre-dressing } \\
\text { serum uric acid } \\
\text { (mg 100/ml) }\end{array}$ & $\begin{array}{l}\text { Methoxyflurane } \\
\text { 'Factor' }\end{array}$ & $\begin{array}{r}\text { Char } \\
\text { serum } \\
\text { (mg } 1\end{array}$ & $\begin{array}{l}\text { ge in } \\
\text { ric acid } \\
0 / \mathrm{ml})\end{array}$ & $\begin{array}{c}\% \\
\text { change }\end{array}$ \\
\hline 9 & 5 & $5 \cdot 4$ & $7 \cdot 5$ & $\begin{array}{l}\text { Day } 2 \\
\text { Day } 3 \\
\text { Day } 4\end{array}$ & $\begin{array}{l}+0.8 \\
+1.1 \\
+0.5\end{array}$ & $\begin{array}{l}+14 \cdot 8 \\
+20 \cdot 3 \\
+\quad 9 \cdot 2\end{array}$ \\
\hline 10 & 5 & $5 \cdot 5$ & $10 \cdot 0$ & $\begin{array}{l}\text { Day } 2 \\
\text { Day } 3 \\
\text { Day } 4\end{array}$ & $\begin{array}{l}+1 \cdot 1 \\
+1 \cdot 3 \\
+1 \cdot 0\end{array}$ & $\begin{array}{l}+20 \cdot 0 \\
+23 \cdot 6 \\
+18 \cdot 1\end{array}$ \\
\hline 11 & 8 & $5 \cdot 6$ & $5 \cdot 0$ & $\begin{array}{l}\text { Day } 2 \\
\text { Day } 3 \\
\text { Day } 4\end{array}$ & $\begin{array}{l}+1 \cdot 1 \\
+1 \cdot 3 \\
+1.0\end{array}$ & $\begin{array}{l}+19.6 \\
+21 \cdot 4 \\
+19.6\end{array}$ \\
\hline 12 & 7 & $5 \cdot 1$ & $12 \cdot 0$ & $\begin{array}{l}\text { Day } 2 \\
\text { Day } 3 \\
\text { Day } 4\end{array}$ & $\begin{array}{l}+0.4 \\
+1.2 \\
+0.4\end{array}$ & $\begin{array}{r}+7.8 \\
+21.5 \\
+\quad 7.8\end{array}$ \\
\hline
\end{tabular}

TABLE 3.

\begin{tabular}{clccc}
\hline \multirow{2}{*}{ Patient } & Day & $\begin{array}{c}\text { BUN } \\
(\mathrm{mg} \mathrm{100/ml})\end{array}$ & $\begin{array}{c}\text { Plasma } \\
\text { protein } \\
(\mathrm{g} / 100 \mathrm{ml})\end{array}$ & $\begin{array}{c}\text { Creatinine } \\
(\mathrm{mg} / 100 \mathrm{ml})\end{array}$ \\
\hline \multirow{2}{*}{9} & Pre & 13 & $7 \cdot 2$ & - \\
& Post 1 & 13 & $7 \cdot 2$ & - \\
& Post 2 & 14 & $7 \cdot 1$ & 0.80 \\
& Post 3 & 14 & $6 \cdot 8$ & 0.62 \\
10 & Pre & 13 & $7 \cdot 2$ & - \\
& Post 1 & 12 & $6 \cdot 7$ & 0.91 \\
& Post 2 & 14 & $6 \cdot 7$ & 0.88 \\
& Post 3 & 15 & $8 \cdot 0$ & 0.96 \\
& Pre & 15 & $7 \cdot 4$ & 0.90 \\
& Post 1 & 14 & $7 \cdot 1$ & 0.94 \\
& Post 2 & 15 & 6.9 & 0.91 \\
& Post 3 & 17 & $7 \cdot 1$ & 0.98 \\
& Pre & 21 & $7 \cdot 6$ & 0.80 \\
& Post 1 & 13 & $7 \cdot 2$ & 0.94 \\
& Post 2 & 16 & $7 \cdot 3$ & 0.95 \\
& Post 3 & 17 & $7 \cdot 1$ & 1.00 \\
\hline
\end{tabular}

the distal tubule and most uric acid excretion takes place at this level.

Aspirin exerts a paradoxical effect on uric acid excretion. In dosage of 1-2 g/day excretion by the distal tubule is prevented and serum uric acid rises. The rise is of the order of $0.2 \mathrm{mg} / 100 \mathrm{ml}$ with a plasma salicylate level of $2.8 \mathrm{mg} \%$. In dosage of 3-4 g/day reabsorption of uric acid in the proximal tubule is inhibited and the net effect is a drop in serum uric acid (Yu \& Gutman, 1955).

All that has been shown in this investigation is that serum uric acid is increased following burns dressings with methoxyflurane analgesia. One patient, who had a repeat dressing with trichloroethylene analgesia, developed a greater rise on this occasion.

It has not been demonstrated whether the rise in serum uric acid is due to impaired excretion or whether it follows tissue destruction during the dressing.

There were rises in blood urea nitrogen (BUN) and creatinine on the third post-dressing day in patients 9, 10,11 and 12. These increases were small but they were consistent, and could have been caused by impaired excretion, metabolic changes or even a relative rise due to loss of body water.

It should be emphasized that in only one patient did we record levels of serum uric acid that were greater than accepted normal limits. Minor alterations in blood chemistry may be enthralling to a biochemist, but they are only important clinically as evidence of impaired renal function, and then only if it is serious enough to have adverse effects on the patients.

Further investigation is essential and should include estimation of serum and urine osmolality, uric acid and creatinine clearance tests and measurements of blood sodium, uric acid, blood urea nitrogen, and plasma protein.

TABLE 4.

\begin{tabular}{clcccc}
\hline Patient & Day & $\begin{array}{c}\text { Trichloroethylene } \\
\text { 'Factor' }\end{array}$ & $\begin{array}{c}\text { BUN } \\
(\mathrm{mg} / 100 \mathrm{ml})\end{array}$ & $\begin{array}{c}\text { Serum uric acid } \\
(\mathrm{mg} / 100 \mathrm{ml})\end{array}$ & $\begin{array}{c}\% \\
\text { change }\end{array}$ \\
\hline \multirow{2}{*}{12} & Pre & 15 & 12 & $5 \cdot 2$ & - \\
& Post 1 & & 5 & $3 \cdot 7$ & $-28 \cdot 8$ \\
& Post 2 & & 11 & $6 \cdot 1$ & $+17 \cdot 3$ \\
& Post 3 & & 14 & $6 \cdot 5$ & $+25 \cdot 0$ \\
\hline
\end{tabular}


Fluid intake and urine output are difficult to record. Alteration in body weight might be a better indication of changes in body water content.

However, any investigation must take account of the fact that burned patients endure much unavoidable pain and discomfort. Venepunctures performed in the interests of research must be restricted to the absolute minimum necessary to determine the pattern of blood constituents.

Methoxyflurane could be used alternately with another analgesic on each patient studied, who would then act as his own control.

\section{Acknowledgments}

We are grateful to Dr G. S. Andrews, Consultant Pathologist in Administrative Charge, and the Laboratory Technicians of the Newport and East Monmouthshire Group of Hospitals for carrying out the biochemistry.

\section{References}

Austin, W.H. \& Villandry, P.J. (1967) Methoxyflurane and renal function. Anesthesiology, 28, 637.

Crandell, W.B., Pappas, S.G. \& MacDonald, A. (1966) Nephrotoxicity associated with methoxyflurane anesthesia. Anesthesiology, 27, 591.

Eger, E.I. \& BrandSTATER, B. (1963) Solubility of methoxyflurane in rubber. Anesthesiology, 24, 679.

EGER, E.I. (1964) Uptake of methoxyflurane in man at constant alveolar and at constant inspired concentration. Anesthesiology, 25, 284.

Elkington, S.J., Goffinet, J.A. \& ConN, H.O. (1968) Renal and hepatic injury associated with methoxyflurane anesthesia. Annals of Internal Medicine, 69, 1229.
Kuzucu, E.Y. (1970) Methoxyflurane, tetracycline and renal failure. Journal of the American Medical Association, 211, 1162.

Lapointe, A. \& Belle-Binda, N. (1970) Nephrotoxicite associee au methoxyflurane. Canadian Anaesthetists' Society Journal, 17, 145.

Lebowitz, M.H. (1969) Nephrogenic diabetes insipidus following methoxyflurane anesthesia: a report of two cases. Anesthesia and Analgesia, 48, 233.

Mazze, R.I., ShUe, G.L. \& JACKSON, S.H. (1971) Renal dysfunction associated with methoxyflurane anesthesia. Journal of the American Medical Association, 216, 278.

Mignault, G., Labrecque, B. \& Hamel, S. (1970) Methoxyflurane et nephtotoxicite: etude de la fonction renale de 22 malades anesthesies au methoxyflurane. Canadian Anaesthetists' Society Journal, 17, 331.

PACKer, K.J. \& Titel, J.H. (1969) Methoxyflurane analgesia for burns dressings: experience with the Analgizer. British Journal of Anaesthesia, 41, 1080.

Panner, B.J., Freeman, R.B., Roth-Mayo, L.A. \& Markowitch, W. (1970) Toxicity following methoxyflurane anesthesia clinical and pathological observations in two fatal cases. Journal of the American Medical Association, 214, 86.

Pezzi, P.J., Frobese, A.S. \& Greenberg, S.R. (1966) Methoxyflurane and renal toxicity. Lancet, i, 823.

SNyDER, R.D., MCCALl, D.M. \& HAYES, M.A. (1966) Functional defect in post-operative polyuric renal failure. Surgical Forum, 17, 19.

Taves, D.R., Fry, B.W., Freeman, R.B. \& Gillies, A.J. (1970) Toxicity following methoxyflurane anesthesia. Fluoride concentrations in nephrotoxicity. Journal of the American Medical Association, 214, 91.

Taves, D.R., Gillies, A.J., Freeman, R.B. \& Fry, B.W. (1970) Toxicity following methoxyflurane anesthesia. Hemodialysis of metabolites. Journal of the American Medical Association, 214, 96.

Yu, T.F. \& Gutman, A.B. (1955) Proceedings of the Society for Experimental Biology and Medicine, 90, 542.

\section{Discussion}

DR A. ENTREsS (London Hospital): Dr Laird raised the subject of uric acid possibly due to disturbance during dressing. I wonder whether a comparison might be valid between say gas and oxygen analgesia and methoxyflurane.

DR LAIRD: Yes. I think this is what must be done. Unfortunately, as I say, the laboratory facilities at Chepstow are inconvenient. The biochemistry is carried out $\mathbf{2 0}$ miles away and sometimes it takes us 4 days to get the results back. It is difficult. If anyone would like to continue the research from here, we would be very grateful to pass it on. I think it may well be unconnected with methoxyflurane. I think it may be due simply to the trauma inflicted on the patient during dressing.

Dr Russell M. Davies: What is the average duration of your dressing?

DR LAIRD: Most are between $30 \mathrm{~min}$ and $45 \mathrm{~min}-$ rarely longer than an hour. In fact, about $80 \%$ are between 35 and $45 \mathrm{~min}$. The amount of methoxyflurane which our patients get is considerably less than the patients in $\mathrm{Dr}$ Mazze's trial. Nearly all the cases of renal dysfunction following methoxyflurane anaesthesia are from across the Atlantic.
Dr MacDonald (Bristol): Is it not possible that the picture that you are drawing comes from renal clampdown from damage rather than from methoxyflurane?

DR LAIRD: I am trying not to present any picture at all. Are you referring to Dr Mazze's paper or are you referring to my own findings?

DR MACDONALD: Your own finding.

DR LAIRD: It is possible, but unlikely. Although we have not got any properly measured urine output, we have not had any indication of either diuresis or oliguria in our patients.

Dr A. W. Diamond (Bristol): Could you tell us a little more about the trichloroethylene? How did it compare clinically with methoxyflurane as an analgesic?

DR LAIRD: Not nearly as good as an analgesic. We are getting away from renal function now, I am afraid, but methoxyflurane's big advantage over trichloroethylene is that it induces euphoria in the patients. In fact, those who were experienced in the matter said it was rather like having two or three whiskies and it made them feel better, in addition to its analgesic properties. Trichloroethylene did not have any such effect on the patients. In fact, it very often depressed the patients at the end of the 
dressing, compared with the beginning. Trichloroethylene, in fact, is not nearly as effective. We are at the moment comparing methoxyflurane with Entonox, and methoxyflurane is the better of the two analgesics.

Mr RINGROSE: There will be a study published shortly from the Welsh National School of Medicine on the effect of Penthrane analgesia in obstetrics. There has been an investigation into the effect on renal function here. I am afraid I have not seen the paper, but I think my colleague, Dr Bennett, may have done.
DR BENNETT: I have been pushed into this! You cannot quite compare them, because they were not looking into the same thing as Dr Laird has been looking into. This survey has shown that so far there has been no difference in renal function between two groups, one treated with nitrous oxide and the other treated with Penthrane.

DR RUSSEll M. DAVIES: It would appear, without wishing to underline anything, that the cloud is lifting slowly, for which I am sure many of us are very relieved. Thank you very much indeed, Dr Laird. 